\title{
Spatial and temporal variations in airborne Ambrosia pollen in Europe
}

\author{
B. Sikoparija - C. A. Skjøth - S. Celenk - C. Testoni • T. Abramidze • K. Alm Kübler • \\ J. Belmonte $\cdot$ U. Berger $\cdot$ M. Bonini $\cdot$ A. Charalampopoulos $\cdot$ A. Damialis $\cdot$ B. Clot $\cdot$ \\ Å. Dahl • L. A. de Weger • R. Gehrig • M. Hendrickx • L. Hoebeke • N. Ianovici • \\ A. Kofol Seliger - D. Magyar · G. Mányoki - S. Milkovska - D. Myszkowska • A. Páldy • \\ C. H. Pashley $\cdot$ K. Rasmussen $\cdot$ O. Ritenberga $\cdot$ V. Rodinkova $\cdot$ O. Rybníček $\cdot$ \\ V. Shalaboda $\cdot$ I. Šaulienè · J. Ščevková • B. Stjepanović • M. Thibaudon • C. Verstraeten • \\ D. Vokou $\cdot$ R. Yankova $\cdot$ M. Smith
}

Received: 14 May 2016/Accepted: 14 October 2016/Published online: 17 November 2016

(C) Springer Science+Business Media Dordrecht 2016

\begin{abstract}
The European Commission Cooperation in Science and Technology (COST) Action FA1203 "SMARTER" aims to make recommendations for the sustainable management of Ambrosia across Europe and for monitoring its efficiency and cost-effectiveness. The goal of the present study is to provide a baseline for spatial and temporal variations in airborne Ambrosia pollen in Europe that can be used for the
\end{abstract}

Electronic supplementary material The online version of this article (doi:10.1007/s10453-016-9463-1) contains supplementary material, which is available to authorized users.

B. Sikoparija

BioSense Institute - Research Institute for Information Technologies in Biosystems, University of Novi Sad, Novi Sad, Serbia

C. A. Skjøth $(\bowtie)$

National Pollen and Aerobiology Unit, Institute of Science and the Environment, University of Worcester, Henwick Grove, Worcester WR2 6AJ, UK

e-mail: c.skjoth@worc.ac.uk

S. Celenk

Biology Department, Science Faculty, Uludağ University, Bursa, Turkey

C. Testoni · M. Bonini

Local Health Authority Milano Città Metropolitana, Milan, Italy

T. Abramidze

Center of Allergy and Immunology, Tbilisi, Georgia management and evaluation of this noxious plant. The study covers the full range of Ambrosia artemisiifolia L. distribution over Europe $\left(39^{\circ} \mathrm{N}-60^{\circ} \mathrm{N} ; 2^{\circ} \mathrm{W}-45^{\circ} \mathrm{E}\right)$. Airborne Ambrosia pollen data for the principal flowering period of Ambrosia (August-September) recorded during a 10-year period (2004-2013) were obtained from 242 monitoring sites. The mean sum of daily average airborne Ambrosia pollen and the number of days that Ambrosia pollen was recorded in the air were analysed. The mean and standard deviation (SD) were calculated regardless of the

K. Alm Kübler

Swedish Museum of Natural History, Stockholm, Sweden

J. Belmonte

Institute of Environmental Science and Technology

(ICTA), Universitat Autònoma de Barcelona, Bellaterra, Barcelona, Spain

J. Belmonte

Departament de Biologia Animal, Biologia Vegetal i

Ecologia, Universitat Autònoma de Barcelona, Bellaterra, Barcelona, Spain

U. Berger

Department of Oto-Rhino-Laryngology, Medical University of Vienna, Vienna, Austria

A. Charalampopoulos · A. Damialis · D. Vokou Department of Ecology, School of Biology, Aristotle University of Thessaloniki, Thessaloniki, Greece 
number of years included in the study period, while trends are based on those time series with 8 or more years of data. Trends were considered significant at $p<0.05$. There were few significant trends in the magnitude and frequency of atmospheric Ambrosia pollen (only $8 \%$ for the mean sum of daily average Ambrosia pollen concentrations and $14 \%$ for the mean number of days Ambrosia pollen were recorded in the air). The direction of any trends varied locally and reflected changes in sources of the pollen, either in size or in distance from the monitoring station. Pollen monitoring is important for providing an early warning of the expansion of this invasive and noxious plant.

Keywords Aerobiology $\cdot$ Ragweed $\cdot$ Invasive alien species $\cdot$ Allergen $\cdot$ Exposure

\section{Introduction}

Ambrosia artemisiifolia L. (common or short ragweed) has been considered to be an invasive and alien plant by the European and Mediterranean Plant Protection Organization since 2004 (Brunel et al. 2010). It is an important weed in agriculture and source of highly allergenic pollen. The plant has now

\footnotetext{
A. Damialis

Chair and Institute of Environmental Medicine, UNIKA-

$\mathrm{T}$, Technical University of Munich and Helmholtz

Zentrum München - German Research Center for

Environmental Health, Augsburg, Germany

B. Clot $\cdot$ R. Gehrig

Federal Office of Meteorology and Climatology

MeteoSwiss, Zurich, Switzerland

A. Dahl

Department of Plant and Environmental Sciences, University of Gothenburg, Gothenburg, Sweden

\section{A. de Weger}

Department of Pulmonology, Leiden University Medical

Center, Leiden, The Netherlands

M. Hendrickx · L. Hoebeke · C. Verstraeten

Belgian Aerobiology Network, Scientific Institute of

Public Health, Brussels, Belgium

N. Ianovici

Faculty of Chemistry-Biology-Geography, West

University of Timisoara, Timisoara, Romania
}

become naturalized in Europe and frequently forms part of the flora (Smith et al. 2013). The prevalence of sensitization to Ambrosia pollen allergens is increasing in Europe and reflects the expansion of Ambrosia populations (Burbach et al. 2009b).

Aerobiological monitoring sites routinely collect and report levels of atmospheric pollen across Europe. The samples are examined by light microscopy, and the data can be used for a variety of purposes, including being an early warning of the spread of invasive, wind-pollinated (anemophilous) plants like Ambrosia artemisiifolia. The pollen grains of $A$. artemisiifolia are morphologically similar to the other introduced species of Ambrosia in Europe, A. trifida L., A. tenuifolia Spreng. and A. psilostachya DC. (=A. coronopifolia Torr. \& Gray) as well as the native $A$. maritima L. (Smith et al. (2013) and references therein). As a result, the pollen grains of Ambrosia species are identified to genus level by monitoring stations.

The threat posed by Ambrosia has been identified, and efforts to reduce the negative impacts on the human population have started to be implemented at national and European levels (Smith et al. 2013). The European Commission Cooperation in Science and Technology (COST) Action FA1203 "SMARTER" (http://ragweed.eu) aims to make recommendations

\author{
A. Kofol Seliger \\ Institute of Public Health of the Republic of Slovenia, \\ Ljubljana, Slovenia \\ D. Magyar · G. Mányoki · A. Páldy \\ National Public Health Center, Budapest, Hungary \\ S. Milkovska \\ Institute of Occupational Health - WHO Collaborating \\ Center, Skopje, Republic of Macedonia \\ D. Myszkowska \\ Department of Clinical and Environmental Allergology, \\ Jagiellonian University Medical College, Kraków, Poland \\ C. H. Pashley \\ Institute for Lung Health, Department of Infection, \\ Immunity \& Inflammation, University of Leicester, \\ Leicester, UK \\ K. Rasmussen \\ Astma-Allergi Danmark, Roskilde, Denmark
}


for the sustainable management of Ambrosia across Europe and for monitoring its efficiency and cost-effectiveness. This study has been conducted within the frame of Working Group 4 of SMARTER, with the goal of providing a baseline for spatial and temporal variations in airborne Ambrosia pollen in Europe that can be used for the management and evaluation of this noxious plant.

\section{Materials and methods}

\subsection{Collection of pollen data}

Pollen data were collected by airborne pollen-monitoring networks across Europe by using volumetric spore traps of the Hirst design (Hirst 1952), thereby ensuring the comparability of the data, and samples were analysed using methods recommended in the literature (Galán et al. 2014). Daily average pollen concentrations are expressed as particles per cubic metre of air $\left(\mathrm{P} \mathrm{m}^{-3}\right)$ (Comtois 1998). The protocol for collating the pollen data was based on the methods described by Thackeray et al. (2010) and Ziello et al. (2012) that were adjusted for the needs of this study. Datasets were restricted to the period August-September, which is the principal flowering period of Ambrosia (Bonini et al. 2015), and the years 2004-2013 only. Within this period, the analyses

O. Ritenberga

Faculty of Geography and Earth Sciences, University of Latvia, Riga, Latvia

V. Rodinkova

Vinnitsa National Pirogov Memorial Medical University, Vinnitsa, Ukraine

\section{O. Rybníček}

Faculty of Medicine, Masaryk University, Brno, Czech Republic

V. Shalaboda

V. F. Kuprevich Institute for Experimental Botany of the NAS of Belarus, Minsk, Belarus

I. Šaulienè

Department of Environmental Research, Siauliai

University, Šiauliai, Lithuania

J. Ščevková

Faculty of Natural Sciences, Comenius University

Bratislava, Bratislava, Slovakia examined the sum of daily average Ambrosia pollen concentrations and the number of days when daily average concentrations exceeded $1 \mathrm{P} \mathrm{m}^{-3}$. The study focuses on a 10-year period (2004-2013). This is because it allows comparison between datasets, as not all sites have been monitoring airborne pollen for long periods of time (i.e. $>10$ years).

Participants included individual sites as well as regional and national pollen-monitoring networks, encompassing a number of countries involved in the COST SMARTER network. Ambrosia pollen data were unavailable for the study from several countries (Figs. 1, 2). For instance, due to constraints in time and resources, a number of sites routinely cease monitoring in August or September, while Ambrosia plants are flowering. At other sites, such as in Portugal, Ambrosia pollen is rarely found in the atmosphere and as such it is not considered to be of allergological importance. As a result, Ambrosia pollen grains are only identified to family level (i.e. Asteraceae) (E. Caeiro, personal communication). This also applies to parts of Spain, but Catalonia was included because Ambrosia pollen is recorded in this region (FernándezLlamazares et al. 2012). The German Pollen Information Service (PID) did not participate in the current study, but data about spatial variations in ragweed populations and the annual Ambrosia pollen index in Germany (2012-2014) are available in the recent paper by Buters et al. (2015). It is also important to

B. Stjepanović Institute of Public Health "Dr Andrija Štampar”, Zagreb, Croatia

M. Thibaudon

Réseau National de Surveillance Aérobiologique (R.N.S.A.), Brussieu, France

R. Yankova

Clinical Center of Allergology, University Hospital Sofia, Sofia, Bulgaria

M. Smith

Institute of Science and the Environment, University of Worcester, Henwick Grove, Worcester WR2 6AJ, UK 
Fig. 1 The location of pollen-monitoring sites involved in the study, showing the following results calculated using the mean sum of available daily airborne pollen

concentrations from August to September during the years 2004-2013: a the mean sums of airborne Ambrosia pollen concentration; b significant trends and the direction of slope of linear regression analysis (only sites with $\geq 8$ years of pollen data). Regions where pollen data were not available are also depicted
A

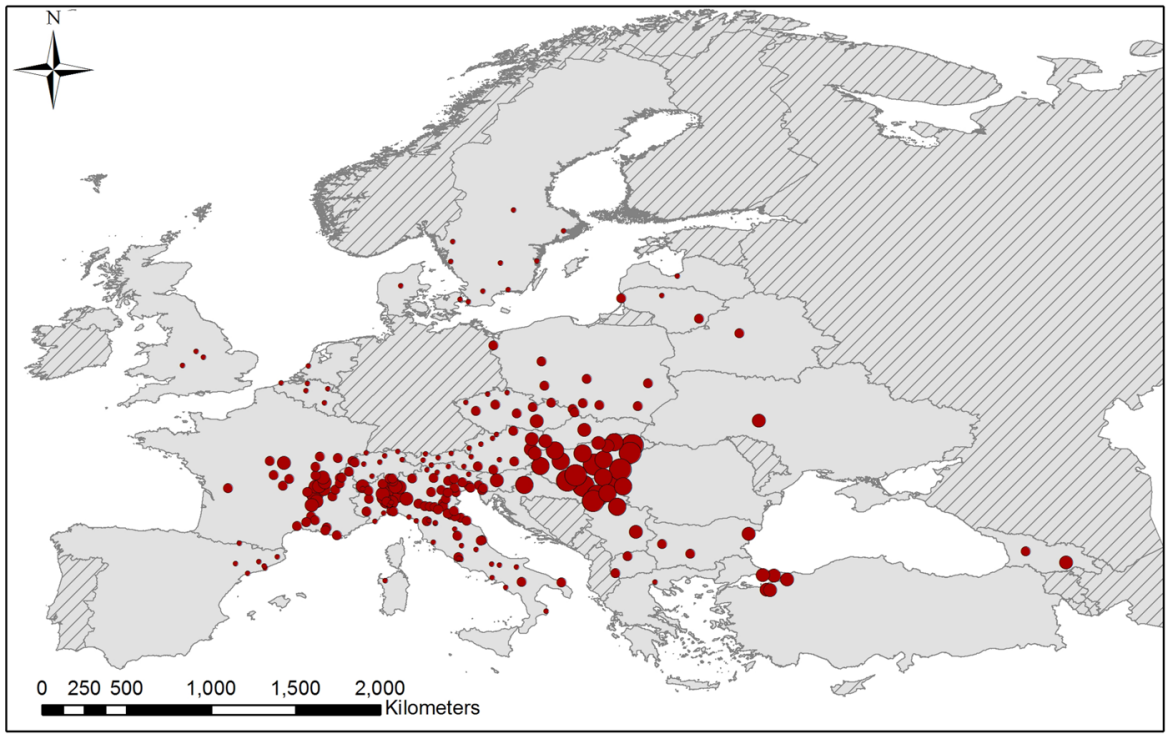

Mean sum of airborne Ambrosia pollen (2004-2013)

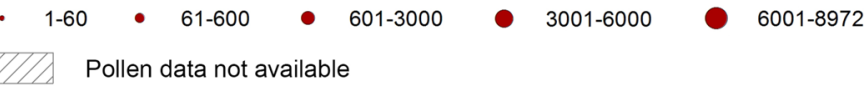

B

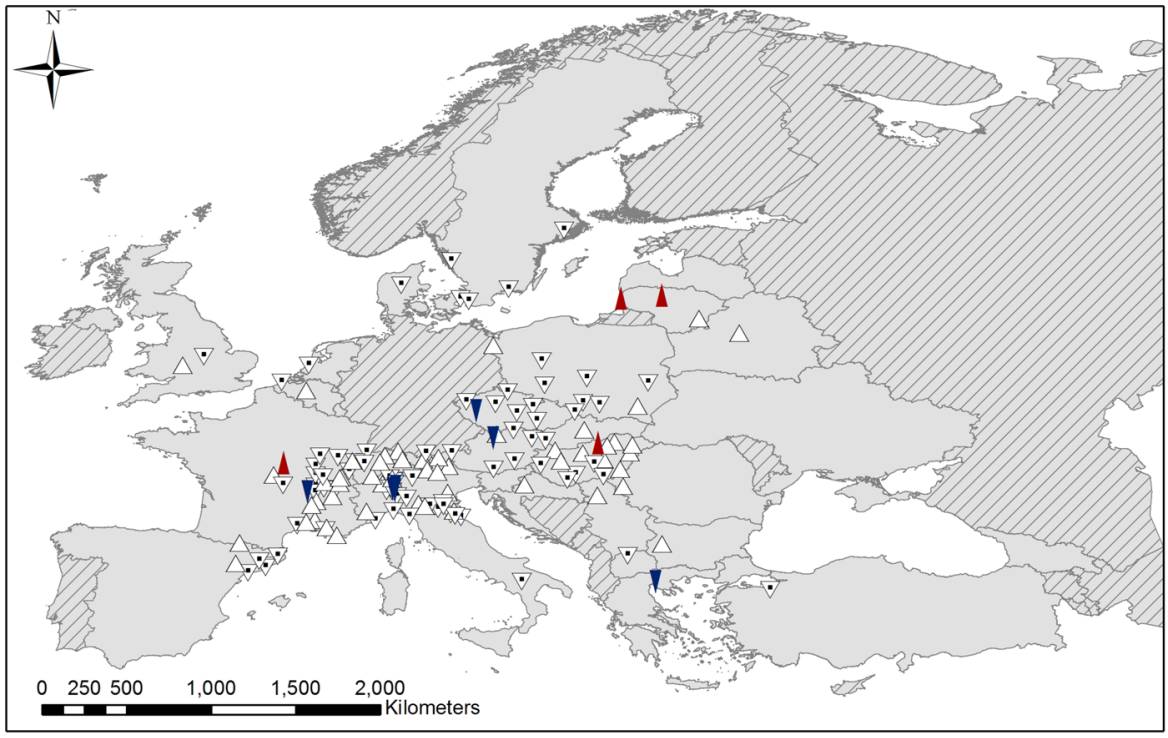

Direction of the trend from linear regression analysis

$\nabla$ Decrease $\triangle$ Increase $\backslash$ Significant decrease $\quad$ S Significant increase
W/A Pollen data not available note that for several spatially large countries (i.e. Romania, Turkey and Ukraine) pollen-monitoring networks are not dispersed over the entire territory, and so the data included in this study are not representative of the entire area of these vast countries.
2.2 Data preprocessing and statistical analysis

Datasets were examined for missing values and irregularities. Years that had more than 7 days missing from the flowering period of Ambrosia were removed 
Fig. 2 The location of pollen-monitoring sites involved in the study, showing the following results calculated using the available number of days when airborne Ambrosia pollen data were recorded during August-September for the years 2004-2013: a the mean number of days when Ambrosia pollen was recorded (maximum 61); b significant trends and the direction of slope of linear regression analysis (only sites with $\geq 8$ years of pollen data). Regions where pollen data were not available are also depicted

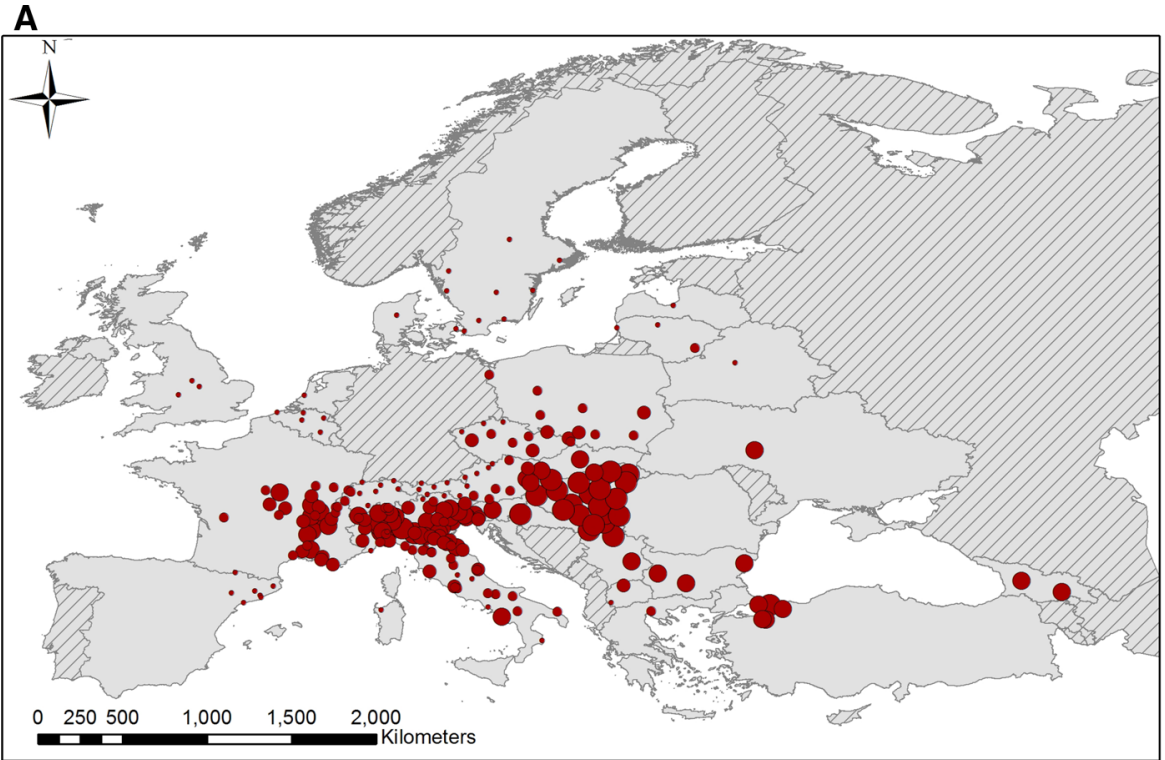

Mean number of days when airborne Ambrosia pollen recorded (2004-2013)
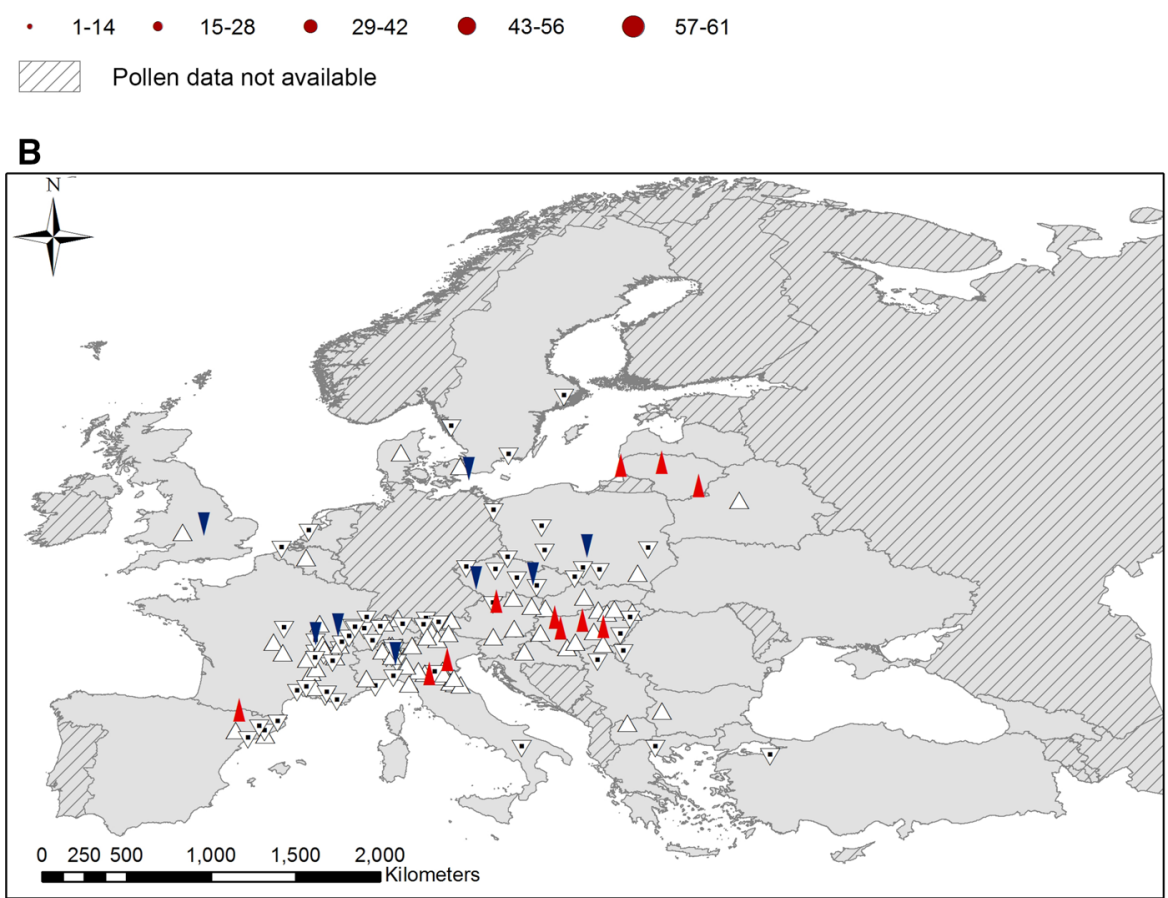

Direction of the trend from linear regression analysis

$\nabla$ Decrease $\triangle$ Increase

$\checkmark$ Significant decrease

$\triangle$ Significant increase

Pollen data not available

from the analysis because it was deemed that this would have a noticeable effect on the results. The mean and standard deviation (SD) were calculated regardless of the number of years included in the study period. On the other hand, linear trends in the sum of pollen recorded annually and the number of days when Ambrosia pollen grains were recorded during August and September each year were calculated (Thackeray 
et al. 2010; Ziello et al. 2012; Smith et al. 2014) for sites with at least $80 \%$ records ( $\geq 8$ years) in the study period and the following results presented: slope of the simple linear regression over time, standard error of the regression slope (SE), probability level $(p)$ and coefficient of determination $\left(R^{2}\right)$. Trends were considered significant with probability levels $<0.05$.

\section{Results and discussion}

A total of 1730 datasets (years of pollen data), from 242 locations, were included in the analysis. Trends were calculated for 143 locations (see Appendix S1 in Supporting Information). Trends were only calculated for sites with $\geq 8$ years of pollen data, but mean values for the sum of daily average Ambrosia pollen concentrations recorded annually and the number of days that Ambrosia pollen was recorded in the air were included for all sites, regardless of the length of the dataset, because it allowed valuable data to be included in the analysis. For example, aerobiological monitoring in Georgia is still developing and only 2 years of data were available for this study. However, habitat suitability analysis for the country predicts that Ambrosia artemisiifolia L. has a distribution of $24 \%$, increasing to $40 \%$ over the next 50 years (Thalmann et al. 2015), which is reflected in this study by the atmospheric pollen levels and number of days in August and September that Ambrosia pollen is recorded (Figs. 1a, 2a).

\subsection{The sum of pollen recorded annually}

This study agrees with previous work showing that France, Northern Italy, the Pannonian Plain and Ukraine (Fig. 1a) record some of the highest levels of airborne Ambrosia pollen in Europe (Skjøth et al. 2013). Mean levels of atmospheric Ambrosia pollen tend to decrease away from these centres, e.g. towards the Atlantic and Baltic coasts in the north and the Mediterranean in the south, although elevated levels of atmospheric Ambrosia pollen were also recorded in the Black Sea region in Turkey and Georgia. It has been hypothesized that airborne Ambrosia pollen in Turkey originates from both local sources and longdistance transport (Zemmer et al. 2012). The plant had previously been reported to be well established in Northeast Anatolia (Byfield and Baytop 1998), and experts belonging to COST SMARTER recently confirmed the occurrence of limited populations of Ambrosia in the vicinity of Samsun near to the Black Sea coast (B. Chauvel, personal communication). It is also predicted that Georgia has notable local Ambrosia populations (Thalmann et al. 2015).

Out of a total of 143 trends for the sum of atmospheric Ambrosia pollen calculated using 8 or more years of data, only 11 were significant ( $8 \%$ ) and 7 of these were towards significant decreases in the amount of airborne Ambrosia pollen. Several of these significant decreases were calculated at sites already considered to be centres of Ambrosia infestation, i.e. Rhône-Alpes region in France and Northern Italy. Such decreases may be the result of successful control measures against Ambrosia in these areas or, in the case of Northern Italy, the accidental introduction of the Ophraella communa leaf beetle that has coincided with a significant decrease in atmospheric concentrations of Ambrosia pollen in the region (Bonini et al. 2015, 2016). This confirms that factors determining the rate of spread of Ambrosia within its current climatic niche (Hamaoui-Laguel et al. 2015) can affect pollen concentrations even without changing the plant distribution.

Hamaoui-Laguel et al. (2015) predicted that atmospheric Ambrosia pollen concentrations would increase up to a factor of two in current high pollen level areas like the Pannonian Plain but, as yet, this has not been seen. Instead, this study has shown that significant increases in the amount of airborne Ambrosia pollen tended to be in areas considered to be at the forefront of Ambrosia expansion, such as Nevers in France and Salgótarján in Hungary, which are on the periphery of the main centres of Ambrosia (Skjøth et al. 2010; Thibaudon et al. 2014; Karrer et al. 2015). Although significant increases were also witnessed at sites situated some distance away from areas traditionally considered to be the heart of Ambrosia infestation, i.e. Lithuania. This discrepancy between monitored pollen data and values expected by the models implies that future distribution of invasive weeds, including their abundance, is affected both by climate conditions and by local anthropogenic influences. Therefore, assessment of Ambrosia biogeography and rates of distribution change in the plant's nonnative distribution range, would benefit from integrating population dynamics and anthropogenic drivers, such as mechanisms for local and long-distance seed dispersal (Chapman et al. 2016). 
3.2 The number of days when Ambrosia pollen was recorded

The number of days when Ambrosia pollen grains were recorded during August and September generally decreased with increased distance away from known centres of Ambrosia infestation (Fig. 2a). This probably reflects the intermittent nature of atmospheric transport episodes from areas with notable sources of Ambrosia pollen to areas where the plant is less common, or not found at all (Stach et al. 2007; Smith et al. 2008; Sikoparija et al. 2009; Kasprzyk et al. 2011; Šikoparija et al. 2013; Sommer et al. 2015). The results show that Ambrosia pollen is also frequently recorded in the Balkans, Greece, Turkey and Georgia. Some of these countries record lower Ambrosia pollen levels (Fig. 1a), but the number of days that people are exposed to this aeroallergen is high. Frequent exposure to low amounts of Ambrosia pollen allergens might explain why the crude clinically relevant sensitization rate to Ambrosia pollen allergens presented by Burbach et al. (2009a) for Greece ( 5\%), is similar to those recorded in Austria (Vienna), France (Montpellier) and Poland (Lodz) that are closer to the Ambrosia heartlands.

The amount of significant trends in the number of days when Ambrosia pollen was recorded was low (just 14\%). As with the sum of airborne Ambrosia pollen recorded in August-September, there is a tendency for sites removed from centres of Ambrosia distribution to exhibit significant trends towards more days with Ambrosia pollen in the air (Fig. 2a). Where local sources of Ambrosia plants are not present or only sporadically recorded (e.g. Lithuania, Sauliene et al. 2011), these trends towards more frequent exposure to airborne Ambrosia pollen might reflect: (1) increases in the magnitude of nearby sources, (2) a decrease in the distance between the site and the source caused by successful invasions (Leiblein-Wild et al. 2014) that would increase the risk of pollen being transported to an area more frequently or (3) conditions becoming more conducive for atmospheric transport (Hamaoui-Laguel et al. 2015).

Prior to conducting this study, it was expected that Ambrosia pollen levels would be comparatively stable in areas considered to be centres of Ambrosia distribution where the plant has been present for considerable lengths of time. If anything, it was anticipated that the amount of airborne Ambrosia pollen or the frequency that Ambrosia pollen was recorded in the air might decrease in these areas due to factors such as management. However, significant increases in the number of days with Ambrosia pollen in the air were witnessed in Hungary on the Pannonian Plain where the plant has been considered to be a problem weed since the 1960s (Smith et al. (2013) and references therein), which suggests that episodes of airborne Ambrosia pollen are actually increasing in frequency in some areas. This concurs with HamaouiLaguel et al. (2015) who postulate that conditions will become more favourable for the release and atmospheric accumulation of Ambrosia pollen from the plant. Nevertheless, it is possible that, for sites with stable Ambrosia populations that record Ambrosia pollen almost every day during August and September, missing days will have an impact on the results. For this reason, care was taken to ensure that years with more than 7 missing values (e.g. due to trap failure) during the principal flowering period of Ambrosia were not included in the analysis.

There are a number of other local differences in the number of days that Ambrosia pollen has been recorded in different regions (Fig. 2b). For instance, Ambrosia plants are rarely recorded in Lithuania to the north-east of the study area (Sauliene et al. 2011). The number of Ambrosia plants in Lithuania is not increasing, but an increase in atmospheric concentrations of Ambrosia pollen has been noted and linked with the occurrence of south-easterly winds and potential long-distance transport (Šaulienè and Veriankaite 2012). Long-distance transport of Ambrosia pollen has also been witnessed in Catalonia to the south-west of the study area, although airborne pollen records in the region could also be substantially influenced by local populations of Ambrosia species that reportedly increased by $324 \%$ (Fernández-Llamazares et al. 2012). This might explain the significant increase in the number of days when Ambrosia pollen has been recorded in the air of north-eastern Spain in this study. In Northern Italy, on the other hand, a significant decrease in the number of days with airborne Ambrosia pollen was witnessed to the North of Milan (Vertemate con Minoprio). This is the region where the oligophagous leaf beetle Ophraella communa, which is known to feed on A. artemisiifolia, has been sighted (Müller-Schärer et al. 2014) and potentially linked to decreases in atmospheric concentrations of Ambrosia pollen reported at some sites 
(Bonini et al. 2015). Conversely, significant increases in the number of days with airborne Ambrosia pollen were seen at sites situated in the Po Valley to the south (Modena) and east (Padua), which might indicate further expansion of Ambrosia in these areas.

This study shows spatial and temporal variations in the magnitude of airborne Ambrosia pollen concentrations and the number of days that the pollen is recorded in the air during the principal flowering period of Ambrosia over a 10-year period (2004-2013) at sites across Europe. The map of Ambrosia distribution in Europe is constantly changing with the inclusion of new data, as seen with the addition of Georgia in this study. The number of significant trends in the magnitude and frequency of atmospheric Ambrosia pollen is low (only $8 \%$ for the mean sum of daily average Ambrosia pollen concentrations and $14 \%$ for the mean number of days Ambrosia pollen were recorded in the air), and the direction of any changes varies locally. These trends reflect variations in sources of the pollen. Significant decreases can be related to external factors such as the introduction of control measures or herbivores that target the plant. Significant increases, on the other hand, can relate to expansions in the size of the source or a shortening of the distance from the source to the monitoring station, thereby increasing the magnitude and frequency of atmospheric pollen concentrations. However, the influence of short-term variations in local weather conditions or long-term effects climate change on the production, release and dispersion of Ambrosia pollen cannot be discounted. This study highlights the importance of pollen-monitoring networks, especially those that do not currently record Ambrosia, to commence actively looking for the pollen of this invasive and noxious plant, even if it is not currently considered to be an important aeroallergen in certain regions. This will provide an early warning of its expansion to new areas.

Acknowledgements We acknowledge support from EU COST Action FA1203 "Sustainable management of Ambrosia artemisiifolia in Europe (SMARTER)" (http://ragweed.eu). The authors acknowledge the A.I.A. (Italian Association of Aerobiology) and the Italian ARPAs (Regional Environmental Protection Agencies) for providing Italian pollen data. This work was partly financed by the following COST Short Term Scientific Missions: COST-STSM-FA1203-020215-053027 to CT, COST-STSM-FA1203-20573, ECOST-STSM-FA1203250415-058150. B. Sikoparija is supported by Ministry of Science Republic of Serbia project no. III43002, C. A. Skjøth is supported by European Commission through a Marie Curie Career Integration Grant (Project ID CIG631745) and Danish Research Council, Acronym SUPREME. C. H. Pashley is supported by the Midlands Asthma and Allergy Research Association (MAARA) and the National Institute for Health Research Leicester Respiratory Biomedical Research Unit and the views expressed are those of the author(s) and not necessarily those of the NHS, the NIHR or the Department of Health. Sevcan Celenk is supported by Research Foundation of Uludag University project no 2011/76 and The Scientific and Technological Research Council of Turkey (TUBITAK) project no 109S032. The authors would also like to thank the following for their expert technical assistance: Iveta Lankova $\dagger$, the National Institute of Public Health, Praha, Czech Republic; J. Corden and W. Millington, Midlands Asthma and Allergy Research Association (MAARA), UK; A. Fairs, Department of Infection, Immunity \& Inflammation, University of Leicester, UK; D. Gioulekas, Pulmonary Department, G.P. Hospital "G. Papanikolaou", Aristotle University of Thessaloniki, Greece; Predrag Radišić, University of Novi Sad, Serbia.

Author's contributions MS, CAS and BS designed the study, analysed and collated results and prepared the manuscript. Raw data analysis and editing of the draft manuscript were performed by BS, CAS, SC, CT, TA, KAK, JB, MB, AC, AD, BC, AD, LAW, JD, RG, MH, LH, NI, AKS, DM, GM, SM, DM, AP, CHP, KR, OR, VR, OR, VS, IS, JS, BS, MT, CV, DV, RY and MS.

\section{References}

Bonini, M., Šikoparija, B., Prentović, M., Cislaghi, G., Colombo, P., Testoni, C., et al. (2015). Is the recent decrease in airborne Ambrosia pollen in the Milan area due to the accidental introduction of the ragweed leaf beetle Ophraella communa? Aerobiologia, 31(4), 499-513.

Bonini, M., Šikoparija, B., Prentović, M., Cislaghi, G., Colombo, P., Testoni, C., et al. (2016). A follow-up study examining airborne Ambrosia pollen in the Milan area in 2014 in relation to the accidental introduction of the ragweed leaf beetle Ophraella communa. Aerobiologia, 32(2), 371-374.

Brunel, S., Branquart, E., Fried, G., van Valkenburg, J., Brundu, G., Starfinger, U., et al. (2010). The EPPO prioritization process for invasive alien plants. Bulletin OEPP/EPPO, 40, 407-422.

Burbach, G. J., Heinzerling, L. M., Edenharter, G., Bachert, C., Bindslev-Jensen, C., Bonini, S., et al. (2009a). GA2LEN skin test study II: Clinical relevance of inhalant allergen sensitizations in Europe. Allergy, 64(10), 1507-1515.

Burbach, G. J., Heinzerling, L. M., Rohnelt, C., Bergmann, K. C., Behrendt, H., \& Zuberbier, T. (2009b). Ragweed sensitization in Europe-GA(2)LEN study suggests increasing prevalence. Allergy, 64(4), 664-665.

Buters, J. T. M., Alberternst, B., Nawrath, S., Wimmer, M., Traidl-Hoffmann, C., Starfinger, U., et al. (2015). Ambrosia artemisiifolia (ragweed) in Germany. Current presence, allergologic relevance and containment procedure. Allergo Journal International, 24, 108-120. 
Byfield, A. J., \& Baytop, A. (1998). Three alien species new to the flora of Turkey. Turkish Journal of Botany, 22(3), 205-208.

Chapman, D. S., Makra, L., Albertini, R., Bonini, M., Páldy, A., Rodinkova, V., et al. (2016). Modelling the introduction and spread of non-native species: International trade and climate change drive ragweed invasion. Global Change Biology,. doi:10.1111/gcb.13220.

Comtois, P. (1998). Statistical analysis of aerobiological data. In P. Mandrioli, P. Comtois, \& V. Levizzani (Eds.), Methods in aerobiology. Bologna: Pitagora Editrice.

Fernández-Llamazares, Á., Belmonte, J., Alarcón, M., \& LópezPacheco, M. (2012). Ambrosia L. in Catalonia (NE Spain): Expansion and aerobiology of a new bioinvader. Aerobiologia, 28(4), 435-451.

Galán, C., Smith, M., Thibaudon, M., Frenguelli, G., Oteros, J., Gehrig, R., et al. (2014). Pollen monitoring: Minimum requirements and reproducibility of analysis. Aerobiologia, 30(4), 385-395.

Hamaoui-Laguel, L., Vautard, R., Liu, L., Solmon, F., Viovy, N., Khvorosthyanov, D., Essl, F., Chuine, I., Colette, A., Semenov, M. A., Schaffhauser, A., Storkey, J., Thibaudon, M., \& Epstein, M. M. (2015). Effects of climate change and seed dispersal on airborne ragweed pollen loads in Europe. Nature Climate Change, 5, 766-771.

Hirst, J. M. (1952). An automatic volumetric spore trap. The Annals of Applied Biology, 39(2), 257-265.

Karrer, G., Skjøth, C. A., Šikoparija, B., Smith, M., Berger, U., \& Essl, F. (2015). Ragweed (Ambrosia) pollen source inventory for Austria. Science of the Total Environment, 523, 120-128.

Kasprzyk, I., Myszkowska, D., Grewling, Ł., Stach, A., Šikoparija, B., Skjøth, C. A., et al. (2011). The occurrence of Ambrosia pollen in Rzeszów, Kraków and Poznań, Poland: Investigation of trends and possible transport of Ambrosia pollen from Ukraine. International Journal of Biometeorology, 55(4), 633-644.

Leiblein-Wild, M., Kaviani, R., \& Tackenberg, O. (2014). Germination and seedling frost tolerance differ between the native and invasive range in common ragweed. Oecologia, 174(3), 739-750.

Müller-Schärer, H., Lommen, S. T. E., Rossinelli, M., Bonini, M., Boriani, M., Bosio, G., et al. (2014). Ophraella communa, the ragweed leaf beetle, has successfully landed in Europe: Fortunate coincidence or threat? Weed Research, 54(2), 109-119.

Sauliene, I., Gudzinskas, Z., Veriankaite, L., Malciute, A., \& Lesciauskiene, V. (2011). Distribution of Ambrosia plants and airborne pollen in Lithuania. Journal of Food, Agriculture and Environment, 9, 547-550.

Šauliene, I., \& Veriankaitè, L. (2012). Analysis of high allergenicity airborne pollen dispersion: Common ragweed study case in Lithuania. Annals of Agricultural and Environmental Medicine, 19(3), 415-419.

Šikoparija, B., Skjøth, C. A., Alm Kübler, K., Dahl, A., Sommer, J., Grewling, Ł., et al. (2013). A mechanism for long distance transport of Ambrosia pollen from the Pannonian Plain. Agricultural and Forest Meteorology, 180, 112-117.

Sikoparija, B., Smith, M., Skjoth, C. A., Radisic, P., Milkovska, S., Simic, S., et al. (2009). The Pannonian Plain as a source of Ambrosia pollen in the Balkans. International Journal of Biometeorology, 53(3), 263-272.

Skjøth, C. A., Šikoparija, B., Jäger, S., \& EAN. (2013). Pollen sources. In M. Sofiev \& K.-C. Bergmann (Eds.), Allergenic pollen (pp. 9-27). Dordrecht: Springer.

Skjøth, C. A., Smith, M., Sikoparija, B., Stach, A., Myszkowska, D., Kasprzyk, I., et al. (2010). A method for producing airborne pollen source inventories: An example of Ambrosia (ragweed) on the Pannonian Plain. Agricultural and Forest Meteorology, 150, 1203-1210.

Smith, M., Cecchi, L., Skjoth, C. A., Karrer, G., \& Sikoparija, B. (2013). Common ragweed: A threat to environmental health in Europe. Environment International, 61, 115-126.

Smith, M., Jäger, S., Berger, U., Šikoparija, B., Hallsdottir, M., Sauliene, I., et al. (2014). Geographic and temporal variations in pollen exposure across Europe. Allergy, 69(7), 913-923.

Smith, M., Skjoth, C. A., Myszkowska, D., Uruska, A., Puc, M., Stach, A., et al. (2008). Long-range transport of Ambrosia pollen to Poland. Agricultural and Forest Meteorology, 148(10), 1402-1411.

Sommer, J., Smith, M., Šikoparija, B., Kasprzyk, I., Myszkowska, D., Grewling, Ł., et al. (2015). The risk of exposure to airborne Ambrosia pollen from local and distant sources in Europe-An example from Denmark. Annals of Agricultural and Environmental Medicine, 22(4), 625-631.

Stach, A., Smith, M., Skjoth, C. A., \& Brandt, J. (2007). Examining Ambrosia pollen episodes at Poznan (Poland) using back-trajectory analysis. International Journal of Biometeorology, 51(4), 275-286.

Thackeray, S. J., Sparks, T. H., Frederiksen, M., Burthe, S., Bacon, P. J., Bell, J., et al. (2010). Trophic level asynchrony in rates of phenological change for marine, freshwater and terrestrial environments. Global Change Biology, 16, 3304-3313.

Thalmann, D., Kikodze, D., Khutsishvili, M., Kharazishvili, D., Guisan, A., Broennimann, O., et al. (2015). Areas of high conservation value in Georgia: Present and future threats by invasive alien plants. Biological Invasions, 17(4), 1041-1054.

Thibaudon, M., Šikoparija, B., Oliver, G., Smith, M., \& Skjøth, C. A. (2014). Ragweed pollen source inventory for France-The second largest centre of Ambrosia in Europe. Atmospheric Environment, 83, 62-71.

Zemmer, F., Karaca, F., \& Ozkaragoz, F. (2012). Ragweed pollen observed in Turkey: Detection of sources using back trajectory models. Science of the Total Environment, 430, 101-108.

Ziello, C., Sparks, T. H., Estrella, N., Belmonte, J., Bergmann, K. C., Bucher, E., et al. (2012). Changes to airborne pollen counts across Europe. PLoS ONE, 7(4), e34076. doi:10. 1371/journal.pone.0034076. 